DOI: 10.26699/jnk.v1i1.ART.p047-051

This is an Open Access article under the CC BY-SA license (http://creativecommons.org/licenses/by-sa/4.0/)

\title{
HUBUNGAN PERILAKU MINUM TABLET ZAT BESI PADA REMAJA PUTRI DENGAN KADAR HEMOGLOBIN
}

\section{(The Correlation of Fe Tablet Drinking Behavior in Teenagers tith the Level of Hemoglobin)}

\author{
Ery Susanti*), Maria Ulfa**) \\ STIKes Patria Husada Blitar \\ e-mail: riyukicantiq@yahoo.com
}

\begin{abstract}
Introduction: Most of the cases of anemia in Indonesia are caused by the lack of iron in the body since the iron existing in the food consumed does not meet the need. The need of the iron of female teenager is used to replace the lost of the iron during the menstrual cycle. The purpose of this study was to identify relationship between Fe tablet drinking behavior in teenagers with the level of hemoglobin. Method: The research design was quasi eksperiment using one-shot case study research. The research sample was 19 student at STIKes Patria Husada Blitar at May $24^{\text {th }}$ until Juni $22^{\text {nd }}$ 2012, its choosed with purposive sampling. The data collected by observation using checklist. The analisys using spearman rank, with significant level $\leq 0,05$. Result: The result showed that drinking behavior of Fe tablets were not good with the mild anemia hemoglobin level was 26.3 with p-value of 0.009 was obtained. Discussion: A good drinking behavior of iron tablets will result in the raise of hemoglobin levels formed, so that anemia could be prevented.
\end{abstract}

Keywords : behavioral, iron tablets, hemoglobin levels

\section{PENDAHULUAN}

Kurangnya zat besi pada remaja tanpa diimbangi asupan zat besi yang adekuat akan berlanjut pada masa kehamilan saat kehamilan akan menyebabkan pertumbuhan janin tidak optimal, berat badan bayi lahir rendah, resiko perdarahan saat persalinan dan meningkatkan resiko kematian ibu dan bayi. Karena itu sebagian besar pakar Obstetri dan Gizi merekomendasikan suplemen besi sejak pra konsepsi (remaja). Berdasarkan Penelitian Direktorat Gizi Masyarakat RI bekerjasama dengan UNICEF (2004) bahwa suplementasi zat besi cukup diperlukan bagi remaja putri yang anemia, karena meningkatkan status gizinya. Sedangkan pemerintah melalui Dinas Kesehatan RI untuk mencegah dan menanggulangi masalah anemia gizi besi adalah melalui suplementasi zat besi, yaitu Program Penggulangan Anemia Gizi Besi Pada Remaja Putri (PPAGB). Sasaran program perbaikan gizi pada kelompok remaja wanita dianggap strategis didalam upaya memutus simpul siklus masalah gizi.

Pada hakekatnya anemia merupakan keadaan menurunnya kadar haemoglobin, hematokrit dan jumlah sel darah merah di bawah nilai normal yang dipatok untuk perorangan (Arisman, 2004 : 146). Sebagian besar penyebab anemia di Indonesia adalah kekurangan zat besi dalam tubuh karena kandungan zat besi dari makanan yang dikonsumsi tidak mencukupi kebutuhan. Anemia karena kekurangan zat besi ini lazim disebut anemia defisiensi besi. Menurut dr. Risa Anwar (2004) hingga saat ini anemia defisiensi besi masih didominasi oleh wanita karena siklus haid. Remaja putri membutuhkan besi paling banyak yang digunakan untuk mengganti besi yang terbuang bersama darah haid (Arisman, 2004 : 146 ). Kekurangan besi umumnya menyebabkan pucat, rasa lemah, letih, pusing, kurang nafsu makan, menurunnya kebugaran tubuh, menurunnya kemampuan kerja, menurunnya kekebalan tubuh dan gangguan penyembuhan luka. 
Di samping itu kemampuan mengatur suhu tubuh menurun.

Pada anak-anak kekurangan besi menimbulkan apatis, mudah tersinggung, menurunnya kemampuan untuk berkonsentrasi dan belajar (Almatsier, 2002:256).

Respon positif terhadap pemberian tablet besi dapat dilihat dari peningkatan kadar $\mathrm{Hb}$ sebesar $0,1 \mathrm{~g} / \mathrm{dl}$ sehari mulai hari ke 5 dari konsumsi tablet besi (Arisman, 2004 : 151).

Kenyataannya, anemia defisiensi besi pada remaja putri masih merupakan masalah yang paling lazim di dunia dan menjangkiti lebih dari 600 juta remaja. Perkiraan prevalensi anemia defisiensi besi secara global di dunia sekitar $51 \%$ (Arisman, 2004 : 146). Begitu pula di Indonesia anemia defisiensi besi pada remaja putri merupakan satu masalah gizi yang harus ditangani secara serius. Anemia defisiensi besi pada remaja putri di Indonesia menjadi masalah kesehatan dengan prevalensi > $15 \%$. Dari hasil penelitian ditemukan remaja putri dengan anemia defisiensi besi di Bogor 57,1\% (SKRT,1995), dan di Bandung 40-41\%. Dari penelitian SPMFA (2004) di Jawa Timur terdapat anemia defisiensi besi sebesar $80,2 \%$. Sedangkan data survei anemia defisiensi besi Dinas Kesehatan Kota Kediri menyebutkan prevalensi anemia defisiensi besi sebesar 14,33\% (Rekap Kajian Data Anemia Dinas Kesehatan Kota Kediri 18-20 Agustus 2004). Sedangkan data dari Dinas Kesehatan kabupaten Blitar menunjukkan jumlah anemia pada remaja putri adalah 76 remaja putri (Dinas Kesehatan Kabupaten Blitar, 2011) , padahal penyuluhan tentang Anemia Gizi Besi sudah dilakukan.

Dari hasil penelitian yang dilakukan sebelumnya di Program Studi Kebidanan Kediri tahun 2006 menunjukkan pengetahuan remaja putri tentang anemia defisiensi besi didapatkan hasil 90,48 \% berpengetahuan baik dan motivasi remaja putri untuk mengkonsumsi tablet besi saat menstruasi memiliki motivasi yang tinggi $54,42 \%$. (Aminin, 2006 : 47).Sedangkan yang diperoleh saat dilakukan studi pendahuluan di DIII Kebidanan STIKes
Patria Husada Blitar pada tanggal 19 April 2012 dari 35 remaja putri memiliki pengetahuan dan sikap yang baik tentang tablet zat besi, 7 dari 8 remaja putri yang dilakukan pemeriksaan $\mathrm{Hb}$ sahli menderita anemia defisiensi besi dengan kadar Hb kurang dari 12 gr\% sahli. Hal ini menunjukkan karakteristik yang hampir sama dengan penelitian yang dilakukan oleh peneliti sebelumnya, bahwa remaja putri memiliki pengetahuan dan motivasi yang baik, namun kejadiaan anemia masih meningkat.

Faktor intern yang memegang peranan didalam pembentukan perilaku berupa kecerdasan, persepsi, motivasi, minat, emosi dan sebagainya untuk mengolah pengaruh-pengaruh dari luar. Motivasi merupakan dorongan untuk bertindak untuk mencapai suatu tujuan tertentu. Hasil dari dorongan dan gerakan ini diwujudkan dalam bentuk perilaku (Notoatmodjo, 2003 : 132). Dengan pengetahuan dan motivasi yang baik diharapkan remaja putri juga memiliki perilaku yang baik dalam meminum tablet zat besi.

Dari uraian di atas peneliti tertarik untuk melanjutkan penelitian yang dilakukan oleh peneliti sebelumnya tentang hubungan antara perilaku minum tablet zat besi pada remaja putri dengan kadar hemoglobin di program studi d-3 kebidanan STIKes Patria Husada Blitar.

Rumusan masalah dalam penelitian ini ada hubungan antara perilaku minum tablet zat besi pada remaja putri dengan kadar hemoglobin di program studi d-3 kebidanan STIKes Patria Husada Blitar.

Tujuan umum penelitian adalah untuk mengetahui hubungan antara perilaku minum program studi d-3 kebidanan tablet zat besi pada remaja putri dengan kadar hemoglobin. Tujuan khusus (1) Mengidentifikasi perilaku minum tablet zat besi pada remaja putri(2) mengide ntifikasi kadar hemoglobin setelah pemberian tablet zat besi (3) menganalisis hubungan antara perilaku minum tablet zat besi dengan kadar hemoglobin.

Manfaat praktis penelitian ini sangat berguna untuk menambah pengalaman dan wawasan tentang perilaku minum 
tablet zat besi pada remaja putri terhadap kadar hemoglobin, melatih berfikir dan bersikap kreatif mencari pemecahan masalah mengenai perilaku minum tablet zat besi pada remaja putri dan mencari pemecahan masalah anemia defisiensi besi yang terjadi pada remaja putri. Manfaat teoritis memperbanyak referensi tentang hubungan perilaku minum tablet zat besi pada remaja putri terhadap kadar hemoglobin.

\section{BAHAN dan METODE}

Desain penelitiannya Quasi Eksperiment dengan One Shot Case Study yaitu melakukan observasi selama perlakuan pemberian zat besi dan melakukan mengecekan kadar hemoglobin. Sampel penelitian ini adalah 19 orang pada tanggal 24 Mei - 22 Juni 2012 di program studi D-3 kebidanan STIKes Patria Husada Kota Blitar yang dipilih dengan teknik purposive sampling. Variabel bebasnya adalah perilaku minum tablet zat besi pada remaja putri dan variabel terikatnya adalah kadar haemoglobin. Perlakuan dilaksanakan 4 minggu dengan memberikan tablet zat besi sebanyak 10 tablet kemudian dilakukan tes haemoglobin. Analisis menggunakan uji korelasi Spearman Rank (Rho) dengan tingkat kemaknaan 0,05.

HASIL PENELITIAN

Tabel 1 Perilaku Minum Tablet Zat Besi pada Remaja Putri dengan Kadar Hemoglobin

\begin{tabular}{|c|c|c|c|c|c|c|c|c|}
\hline \multirow[b]{2}{*}{ Perilaku } & \multicolumn{6}{|c|}{ Kadar Hb } & \multirow[b]{2}{*}{ Jumlah } & \multirow[b]{2}{*}{$\%$} \\
\hline & $\begin{array}{c}\text { Anemia } \\
\text { Ringan Sekali }\end{array}$ & $\%$ & $\begin{array}{c}\text { Anemia } \\
\text { Ringan }\end{array}$ & $\%$ & $\begin{array}{l}\text { Anemia } \\
\text { Sedang }\end{array}$ & $\%$ & & \\
\hline Baik & 3 & 15,8 & 0 & 0 & 0 & 0 & 3 & 15,8 \\
\hline Cukup & 1 & 5,3 & 1 & 5,3 & 1 & 5,3 & 3 & 15,8 \\
\hline Kurang & 2 & 10,5 & 4 & 21,1 & 0 & 0 & 6 & 31,6 \\
\hline Tidak baik & 0 & 0 & 5 & 26,3 & 2 & 10,5 & 7 & 36,8 \\
\hline
\end{tabular}

Signifikasi hubungan perilaku minum tablet zat besi pada remaja putri dengan kadar hemoglobin ditunjukkan oleh nilai P-value 0,009.

\section{PEMBAHASAN}

Perilaku Minum Tablet Zat Besi pada Remaja Putri di Program Studi D-3 Kebidanan STIKes Patria Husada Blitar

Perilaku minum tablet zat besi pada remaja putri, hampir setengah responden berperilaku tidak baik yaitu 7 remaja putri $(36,8 \%)$.

Perilaku adalah suatu kegiatan atau aktivitas organisme (makhluk hidup) yang bersangkutan. Sehingga yang dimaksud perilaku manusia pada hakekatnya adalah tindakan atau aktivitas dari manusia itu sendiri yang mempunyai bentangan yang sangat luas antara lain berjalan, bicara, menangis, tertawa, bekerja, kuliah, menulis, membaca dan sebagainya (Notoatmodjo, 2003 : 114). Menurut Suryani (2003) yang diacu dari beberapa buku, perilaku adalah aksi dari individu terhadap reaksi dan hubungan dengan lingkungannya. Perubahan perilaku baru adalah suatu proses yang kompleks dan memerlukan waktu yang relatif lama. Secara teori perubahan perilaku baru melalui 3 tahap pengetahuan, sikap dan tindakan (Notoatmodjo, $2003: 128$ ).

Perubahan-perubahan perilaku dalam diri seseorang dapat diketahui melalui persepsi. Persepsi adalah pengalaman yang dihasilkan melalui indra penglihatan, pendengaran, penciuman dan sebagainya. Motivasi diartikan sebagai dorongan untuk bertindak untuk mencapai suatu tujuan tertentu. Hasil dari dorongan dan gerakan ini diwujudkan dalam perilaku (Notoatmodjo, 2003 : 132).

Dalam penelitian ini responden memiliki perilaku tidak baik dalam minum tablet zat besi. Hal ini disebabkan karena meskipun semua responden memiliki pengetahuan yang baik yang diperoleh dari media elektronik, media cetak dan penyuluhan kesehatan, namun hal tersebut tidak secara otomatis dapat merubah perilaku seseorang. Diperlukan teknis dan strategi serta inovasi dalam 
menumbuhkan perilaku minum tablet zat besi.

Sesuai dengan teori bahwa perilaku dipengaruhi oleh beberapa hal diantaranya adalah pengamatan, perhatian, tanggapan, fantasi, ingatan berfikir dan motif. Kurangnya dukungan dan motivasi juga mempunyai pengaruh yang sangat besar.

Sehingga masih memerlukan pendampingan dalam memfokuskan perhatian, fantasi maupun motivasi dalam minum tablet zat besi. Anemia defisiensi besi dapat disebabkan oleh rendahnya masukan besi, gangguan absorbsi, serta kehilangan besi akibat perdarahan menahun, kebutuhan besi meningkat. Faktor nutrisi akibat kurangnya jumlah besi total dalam makanan atau kualitas besi yang tidak baik ( makanan banyak mengandung serat, rendah vitamin $\mathrm{C}$, dan rendah daging). Menurut Soetjiningsih (2004) gadis yang menstruasi membutuhkan tambahan zat besi yang lebih tinggi.

\section{Kadar Hemoglobin}

Menurut Sunita (2002) kebutuhan tubuh akan besi berpengaruh besar tehadap absorbsi besi. Kekurangan zat besi pada umumnya menyebabkan pucat, rasa lemah, letih, pusing, kurang nafsu makan. Menurunnya kebugaran tubuh, menurunnya kemampuan kerja. Begitupula yang terjadi di program studi d-3 kebidanan STIKes Patria Husada Blitar sebagian besar $(52,6 \%)$ responden memiliki kadar hb anemia ringan. Hal ini dikarenakan kurangnya nutrisi dalam makanan yang dikonsumsi, pengeluaran darah karena menstruasi, serta kebutuhan zat besi tiap individu yang tidak sama sehingga mempengaruhi absorbsi zat besi dalam tubuh. Akibat kekurangan zat besi ini ditunjukkan dengan keluhan pusing, mudah lelah. Sehingga untuk mengantisipasi defisiensi zat besi perlu dilakukan suplementasi zat besi oleh remaja putri. Untuk mengatasi anemia ringan maka remaja putri minum tablet zat besi 1 kali setiap minggu sampai dengan diperoleh kadar hemoglobin normal.

\section{Hubungan Perilaku Minum Tablet Zat Besi pada Remaja Putri dengan Kadar Hemoglobin di Program Studi D-3 Kebidanan STIKes Patria Husada Blitar.}

Pada tabel 1 menunjukkan bahwa sebagian besar $(26,3 \%)$ responden memiliki perilaku tidak baik dengan kadar hemoglobin anemia ringan. Signifikasi hubungan perilaku minum tablet zat besi pada remaja putri dengan kadar hemoglobin ditunjukkan oleh nilai Pvalue sebesar 0,009. Karena nilai $\mathrm{P}$-value $<\alpha$ yang ditetapkan yaitu $5 \%$ maka ada hubungan antara perilaku minum tablet zat besi pada remaja putri dengan kadar hemoglobin di program studi d-3 kebidanan STIKes Patria Husada Blitar.

Menurut Notoatmodjo (2007) mengatakan bahwa meskipun perilaku adalah totalitas respons, sangat tergantung pada karakteristik individual. Sedangkan Arisman (2004) anemia defisiensi besi adalah keadaan dimana kadar hemoglobin, hematokrit dan sel darah merah lebih rendah dari normal, sebagai akibat defisiensi besi. Sesungguhnya masalah defisiensi zat besi cukup diterapi dengan pemberian makanan yang cukup mengandung zat besi. Namun jika anemia sudah terjadi atau kebutuhan zat besi tubuh meningkat, tubuh tidak akan mungkin menyerap zat besi dalam jumlah besar dan dalam waktu yang singkat ( hanya $5 \%-10 \%$ atau $1-2 \mathrm{mg}$ zat besi yang dapat diserap oleh makanan), karena itu digunakan suplemen zat besi.

Hasil penelitian menunjukkan bahwa hampir setengah $(26,3 \%)$ responden memiliki perilaku tidak baik dengan kadar hemoglobin anemia ringan. Hal ini menunjukkan bahwa erat hubungannya antara perilaku minum tablet zat besi dengan kadar hemoglobin.

Perilaku yang tidak baik dalam suplementasi tablet zat besi yang kurang, asupan makanan yang kurang mengandung zat besi, serta absorbsi zat besi dalam tubuh yang tidak sama. Sedangkan anemia ringan adalah kondisi dimana kadar hemoglobin kurang dari normal (8 \%-9,9 \%) yang disebabkan karena faktor nutrisi akibat kurangnya jumlah besi total 
dalam makanan, perdarahan menahun, kebutuhan besi meningkat. Sehingga apabila perilaku minum tablet zat besi tidak baik sehingga penyediaan besi untuk eritropoesis berkurang yang pada akhirnya pembentukan hemoglobin berkurang sehingga terjadilah anemia dimana kadar hemoglobin kurang dari normal.

\section{SIMPULAN dan SARAN SIMPULAN}

Perilaku minum tablet zat besi pada remaja putri cenderung tidak baik yaitu sekitar 36,8 \%, kadar hemoglobin pada remaja putri cenderung anemia ringan yaitu sekitar 52,6\%, Signifikasi hubungan perilaku minum tablet zat besi pada remaja putri dengan kadar hemoglobin ditunjukkan oleh nilai $\mathrm{P}$ value sebesar 0,009 , dengan $\mathrm{P}$-value $<\alpha$ yang ditetapkan yaitu $5 \%$ maka ada hubungan antara perilaku minum tablet zat besi pada remaja putri dengan kadar hemoglobin.

\section{SARAN}

Berdasarkan hasil penelitian, didapatkan bahwa perilaku minum tablet zat besi tidak baik. Untuk itu perlu diadakan pembiasaan dalam mengkonsumsi tablet zat besi, serta gambar-gambar tentang pentingnya zat besi ditiap ruangan perkuliahan sehingga mahasiswi memiliki perhatian, ingatan, imajinasi dan termotifasi sehingga perilaku minum tablet zat besi menjadi lebih baik. Diharapkan mahasiswa dapat meningkatkan kemampuan dalam memberikan penyuluhan mengenai pentingnya suplementasi zat besi Serta dengan mengadakan program bulan $\mathrm{Fe}$ yang difasilitasi oleh organisasi kemahasiswaan yang ada. Hal ini dikarenakan apabila pada remaja putrid mengalami anemia defisiensi besi akan mempengaruhi konsentrasi dalam belajar.

\section{REFERENSI}

Almatsier, S 2004, Prinsip Dasar Ilmu Gizi, Gramedia, Jakarta.

Aminin, F 2006, 'Hubungan Pengetahuan

Remaja Putri tentang Anemia Defisiensi Besi dengan Motivasi Mengkonsumsi Tablet Besi saat menstruasi', Karya Tulis Ilmiah, Program Studi Kebidanan, Kediri.

Arisman 2004, Gizi dalam Daur Kehidupan, EGC, Jakarta.

Dinas Kesehatan Kabupaten Blitar 2011.

Handayani, W 2008, Asuhan Keperawatan pada Klien dengan Gangguan, Sistem Hematologi, Salemba Medika, Jakarta.

Kusmiran, E 2002, Kesehatan Reproduksi Remaja dan Wanita, Salemba Medika, Jakarta.

Notoatmodjo, S 2003, Pendidikan dan Perilaku Kesehatan, Rineka Cipta, Jakarta.

Pieter, HZ dan Namora 2010, Pengantar Psikolog untuk Kebidanan, Kencana, Jakarta.

Santrock, JW 2003, Adolescence Perkembangan Remaja, Erlangga, Jakarta.

Soe, J 2003, Farmakologi Kebidanan, EGC Jakarta.

Soetjiningsih 2004, Tumbuh Kembang Remaja dan Permasalahannya, Sagung Seto, Jakarta 